Article

\title{
Mass Media Reporting and Illicit Harvesting of Russian Crab: Implications for Sustainable Fishery
}

\author{
Andrey Belov ${ }^{1,2, *}$ and Genrietta Soboleva ${ }^{2}$ \\ 1 Faculty of Economics, Fukui Prefectural University, Fukui 910-1195, Japan \\ 2 Faculty of Economics, Saint-Petersburg State University, Saint Petersburg 199034, Russia; \\ sobolg2004@mail.ru \\ * Correspondence: abelov@fpu.ac.jp
}

Received: 29 June 2020; Accepted: 12 August 2020; Published: 16 August 2020

\begin{abstract}
Existing methods of combating the shadow economy do not always give reliable results. This is particularly true for the illegal use of renewable natural resources. In some parts of the Northwest Pacific basin, illegal, unreported, and unregulated (IUU) fishing has become an issue of growing concern for the sustainability of resource management, ecology, and the social environment. Many factors combine to produce these harmful phenomena. The complex legal rights for shared natural marine resources, the weak capacity of state institutions, and the lack of international cooperation between exporters and importers are all relevant. These factors can be eliminated by supplementing the "traditional" analysis of the shadow economy with new data mined from the media. For the crab harvesting regions of Russia, long-lasting benefits can be achieved through improvements in governance, accountability, and public awareness, or more specifically, through extensive mass media coverage of relevant topics. We argue that in the Russian Pacific, levels of illegal crab harvesting and smuggling correlates closely to the frequency of media references. The results suggest possible applications of mass media analysis: developing additional metrics for the dynamics of shadow economies; and the formulation of effective policy recommendations for sustainable fishing.
\end{abstract}

Keywords: sustainable fishing; unobserved economic activity; IUU fishing; fishing controls; illegal crab harvesting; governance; mass media freedom

\section{Introduction}

How to evaluate, analyze, and eliminate the shadow economy is a complex theoretical and practical problem. The complications multiply when the shadow activity crosses national borders and involves illegal trade in marine, forest, and other shared natural resources that are difficult to regulate. In these cases, the existing methods of combating the shadow sector do not give the anticipated results and additional research and policy tools are needed.

One strategy that would appear to be effective is improving governance, accountability, and public awareness. Attaining these goals makes the development of independent mass media and press freedom indispensable parts of a sustainable society. This is because analysis of media, such as papers and articles that address related subject matter, appears to produce valuable results. More specifically, media coverage reflects the dynamics of the shadow economy so closely that an analysis of word usage generates enough information to detect the economy's development, assess its dynamics, and minimize its possible negative consequences. In addition to the quantitative data, the published materials both provide information on and shape public opinion, which in turn influences the creation and structuring of government response. All these factors confirm the importance of studying the 
relationship between the media and the development of shadow activity, both from theoretical and practical points of view.

This paper is devoted to testing the above hypotheses and developing new methods and tools to monitor the shadow economy. The paper is structured as follows: After the introduction, a review of the existing literature on the illegal, unreported, and unregulated (IUU) use and smuggling of natural resources is given. Following that is an overview of the poaching and selling of crabs, which are taken from the Russian Pacific basin and delivered to neighboring countries. The next part explores the correlation between illegal crab harvesting and smuggling and the frequency of media references to relevant topics. The paper concludes with regional policy recommendations and ideas for future study.

\section{Theory and Literature Review}

Much scientific research has been devoted to the study of the shadow economy. Our focus will be on works that seek to define the aspect that may be the hardest to subject to research. This is the unauthorized extraction of renewable natural resources, such as fish and other marine products, timber, and commercially viable species of wild plants or animals. The challenge comes from the lack of private property rights on these resources, which makes it especially difficult to organize or monitor their usage. As a result, in these areas, one often finds evidence of "market failures", including the overexploitation and depletion of reserves in both the economic and biological senses [1]. Normally, market failures are ameliorated or eliminated through state intervention, and it is with this goal in mind that most research on this topic has been conducted thus far.

Among the main issues addressed by the literature on the economy of fisheries are the reasons for non-compliance with established rules of conduct [2,3], the design of regulatory and incentive mechanisms to reduce illegal fishing [4], the impact of subsidies on the behavior of fishing companies [5], and options for the restoration of depleted resources [6]. These interdisciplinary topics, specific to certain regions, resource types, and methods of extraction are, ultimately, extremely complicated and therefore difficult to solve using a traditional economic science framework.

In addition to the challenges of studying market failures and government intervention, the complex classification of natural resource extraction should also be noted. The process can simultaneously include several types of activities. Take, for example, the extraction of crab by only one vessel in one area: within the established quota it is legal; quota overfishing is illegal; concealing part of the catch from tax or customs authorities is considered unreported; and fishing by sailors for personal consumption would be classified as unregulated economic activity. Naturally, these classifications are not always easily disentangled. That is why, since the 1990s the term IUU (illegal, unreported, unregulated) has been widely used in specialized literature and the reports of international environmental organizations [7]. To illustrate the growing appeal of this term, we consider that the first meta-analysis of IUU fishing-related literature included 44 studies [8], but a search for the "IUU fishing" keywords in the Web of Science Core Collection database returned 258 hits on 27 July 2020.

Methods for assessing IUU fishing activities are divided into top-down and bottom-up approaches [9]. Top-down methods use global estimates of the proportion of IUU catch. Bottom-up techniques are based on a comparison of reported catches and actual landings, official and real cash flows, mirror statistics of partner countries on exports and imports, etc. Bottom-up methods also include the simulation modeling of IUU activities and interpolation from direct observations, which in recent years have become increasingly common in research at both national and international levels [10]. Previous studies estimate the extent of IUU fishing activity to be 11-26 million tons or 10-23 billion US dollars per year, which accounts for $13-31 \%$ of the world's total catch [11]. The most affected by IUU are commercially valuable species of Atlantic tuna, Pacific salmon, and crab. In the Northwest Pacific zone, the estimated share of IUU fishing reaches $33 \%$, with $45 \%$ for salmon and $25 \%$ for crab and shrimp [12] (p. 8). IUU activities of such magnitude are associated with enormous ecological, economic, and social costs, which make the reduction of it a growing concern for a number of countries and international organizations. 
The elimination of IUU fishing requires a complex strategy that includes tightening controls in the ports of landing, increasing the information exchanges between trading countries to document catch schemes, restructuring excessive fishery capabilities, creating alternative employment opportunities for fishermen, improving the social environment, etc. Tighter controls per se can bring only limited outcomes, as IUU companies demonstrate almost unlimited possibilities for adjustment, changing harvesting areas, ports of landing, and registrations of fishing vessels [13]. The most comprehensive and long-lasting solution is provided by improvements to the state of governance, with the most important dimensions directly reflecting accountability, public awareness, and media freedom [14]. Therefore, despite its many limitations, mass media is an important tool supplementing traditional methods of studying and combating the shadow economy. Moreover, a direct display of events, fast reaction times, large amounts of data, and advanced processing technologies give the modern media a number of new qualities important for conducting research in this field. Let us try to illustrate the importance of some of these innovations by looking at the example of illegal harvesting and exporting of crab in Far Eastern Russia, where a large informal sector has existed for a long time.

\section{Historical Background and IUU Crab Harvesting Assessment}

Crab harvesting in the waters of the Russian Far East began in the 1870s. For nearly half a century, it was solely conducted by Japanese vessels, as the first Russian crab catcher started operations only in 1928. Japanese activities peaked in 1929 when about 110 thousand tons of king crab were harvested. After that, Japan's crab production began to decline, and by 1940 it was completely terminated. In the 1950s and 1960s, the Soviet Union extracted small amounts of king crabs using somewhat outdated Soviet and Japanese equipment. In the 1970s and 1980s, several modern fishing vessels and floating cannery factories appeared in the Far East waters, starting the large scale extraction of a wide variety of species. At that time, production, processing, and export of crab were effectively monopolized by the "Dalmoreproduct" state-owned enterprise. It is not surprising that in the Soviet period crab harvesting "was highly regulated and the fishing industry was tightly controlled" [15] (p. 10).

Rapid liberalization in the 1990s led to the collapse of state controls on the crab industry. A number of private companies attracted by low entrance costs and high profitability, started crab harvesting, routinely overfishing allowable catch quotas, evading taxes, and violating customs rules. The peak of the predatory fishing took place in 2007 when more than a half of total 180 thousand tons was believed to be caught illegally (Rossiyskaya Gazeta (2015). Under the Title of IUU (in Russian). 16 July 2015. [Electronic source] Available online: https://rg.ru/2015/07/16/reg-dfo/krab.html (Date of access 11.05.2020)). From 1994-2002 alone, the crab trade data showed Japanese total imports exceeding Russian officially reported exports by some 52.1 billion dollars [16]. After that, the discrepancies in customs statistics diminished, going from the truly extreme (Russian and Japanese figures differed by a factor of 30-188 through the 1990s and 2000s), to the very large (a factor of 10-20 throughout the 2010s), and finally to the somewhat more moderate (a factor of 3-7 times from 2015 to 2017). (Federal Customs Service of Russia. Customs Statistics of Foreign Trade. [Electronic source] Available online: http://stat.customs.ru/apex/f?p=201:1:2396256557612734 (Date of access 11.05.2020); Japan Ministry of Finance. Trade Statistic of Japan. [Electronic source] Available online: http://www.customs.go.jp/toukei/info/index_e.htm (Date of access 11.15.2020)).

By that time, crab stocks were depleted to the point of total extinction in many fishing areas. This information emerged as a result of a comprehensive analysis of the production, marketing, and consumption of Russian seafood published by World Wildlife Fund (WWF) specialists [15]. The central element of the study was the assessment of shadow activities based on contrasting actual vs. legally permitted catch.

As for the legally permitted part, most countries impose various restrictions on the harvesting of crab, shrimp, and other marine invertebrates, that is, the most expensive species of natural marine resources within their territorial waters and exclusive economic zone. In Russia, each type of natural resource within a certain area of the sea has a total allowable catch (TAC) determined annually. This 
volume is then distributed among companies in the form of fishing quotas. Harvesting in excess of the established quotas is prohibited and can be unequivocally considered illegal. Therefore, the TAC figures represent a lower limit for the estimation of shadow activity.

The higher limit is determined by the actual amount of extracted crabs. The figures officially reported by harvesting companies are unreliable, as they tend to underreport their catches for purposes of tax evasion and concealing of quota overfishing. Nevertheless, we can estimate the actual catch by combining different sources, because the harvested crabs are either: (1) consumed domestically; (2) refrigerated and temporarily stored; or (3) exported. Unfortunately, for the period 2000-2013, information relating to the first and the second categories is not available. At the same time, domestic consumption in the 2000s was estimated at approximately $20 \mathrm{~g}$ per capita or 2880 tons in 2013. It is a relatively small amount, a mere $3.3 \%$ of international trade in the same year. Also, existing industrial refrigerators in Russia were only capable of freezing crabs at a temperature of minus $18-24^{\circ} \mathrm{C}$ and storing them for approximately three months (Ekspert (2016) U-turn of Crab Industry (in Russian). 29 August 2016. [Electronic source] Available online: https://www.pressreader.com/russia/ekspert/20160829/283188672825253 (Date of access 11.05.2020)). Consequently, the crab stocks that were frozen in one year and then exported the next should be rather small. Finally, exported amounts (the third indicator) are best estimated through mirror statistics of importing countries. Total imports, although they omit domestic consumption and refrigerated stocks, nevertheless reflect the actual harvested amounts with acceptable accuracy.

The difference between the actual catch (as approximated by total imports) and the legally permitted catch (TAC) will be a clear indicator of shadow activity. These figures reported by the WWF and some other specialists represent the best available longitudinal estimation of the shadow sector and can be used as a basis for further research.

The total amount of crab imported from Russia (including triangular trade from transit countries) according to the customs statistics of Canada, China, Japan, South Korea, and the USA, exceeded the TAC by a factor of 1.9 in 2000, 2.6 in 2005, and 1.4 times in 2013. The total volume of illegal deliveries for this period reached 875.7 thousand tons or approximately half $(50.8 \%)$ of all imports. The value of poached crab, even estimated at a low price of $\$ 10$ per kilogram, exceeds $\$ 8.7$ billion [15]. This figure surpasses, by a factor of 10, the gross investments into the fishing industry of Far Eastern Russia for the same period.

Russian authorities were not blind to the problem and took various countermeasures to restore law and order in the industry. More specifically, in 2000 a system of long term (up to 10 years) harvesting quotas was introduced. In 2007-2011 environmental considerations led to a comprehensive ban on the export of live crab from the Russian economic zone. In 2008 a compulsory customs clearance of catch in Russian territory was announced, with the goal of streamlining export procedures. IUU crab exports gradually decreased due to strengthening controls and the increased compliance of fisheries. Nevertheless, the situation was improving so slowly that in December 2013 the Russian government was forced to adopt a special action plan to combat the illegal harvest of crab.

At the same time, an expansion of cooperation with the governments of major importing countries began. From 2008-2015, bilateral agreements for the prevention of illegal fishing were signed with North and South Korea, Japan, China, Canada, and the United States. The agreements were the result of a lengthy negotiation process that overlapped, as described above, with a variety of other actions. Meanwhile, public policy was playing an important role in the negotiations as the problem came to international attention. The WWF highlighted importers' regulatory obligation to take measures against the purchase of illegally obtained products and also offered specific recommendations to consumers of Russian crab [15] (pp. 28-30). The obligation was formalized in the international Agreement on Port State Measures to Prevent, Deter and Eliminate Illegal, Unreported and Unregulated Fishing (PSMA), which went into effect in 2016 and became the "first-ever binding international agreement specifically targeting IUU fishing" (Food and Agricultural Organisation (FAO) (2016). Illegal, Unreported and Unregulated Fishing. [Electronic source] Available online: http://www.fao.org/3/a-i6069e.pdf (Date of 
access 11.05.2020)). With these and other domestic and international measures, the Russian government succeeded in eliminating approximately 80\% of illegal crabs shipments by 2017 (Federal Agency for Fisheries (2017). Record Amount of Crabs is Permitted to Harvest in the Far East (in Russian). [Electronic source] Available online: https://finance.rambler.ru/economics/37197845-na-dalnem-vostoke-razreshilivylovit-rekordnyy-obem-kraba/ (Date of access 11.05.2020)).

Even with this progress, some shadow activities were still taking place. Among them, we can point out the supply of poached crabs via some ports in China and North Korea, illegal harvesting by vessels under the "flags of convenience" (FOC), unreported reloading of crab cargo at the high seas and other types of highly questionable deals. Apparently, the period of rapidly developing shadow activities in this area of Russian trade has ended and the front line in the struggle over the sale of illegal crab has moved from Japan to China and the DPRK [17].

Nevertheless, the problem of shadow activity in crab trade has not yet been fully resolved and requires further attention. In 2017-2018 and the first half of 2019, the gap between Russian data on exports and Japanese figures for imports of live and frozen crab (codes 030614 and 030624 of standard classification SCN FEA) started to grow again (Japan Ministry of Finance. Trade Statistic of Japan. [Electronic source] Available online: http://www.customs.go.jp/toukei/info/index_e.htm (Date of access 11.05.2020)). While technical differences in reporting explain a large part of the statistical imbalance, the scale and duration of the inconsistencies clearly indicate that the illicit crab trade between Japan and Russia has experienced a resurgence as the controlling powers have switched their focus to other countries.

This particular battle with the shadow sector took almost a quarter of a century but did not achieve the anticipated results. During this time, crab resources were brought to the verge of catastrophic decline, which could result in the collapse of crab stocks in part or all of the Russian Far East [15] (pp. 27-28). The fishing industry and regional budgets lost substantial investment; and tax fraud, corruption, and other abuses spread among the harvesters, exporters, and regional authorities. It is noteworthy to mention that in 2000, 188 companies, 380 ships, and more than 10,000 sailors were engaged in crab harvesting in the Far East of Russia, (Federal Antimonopoly Service (2004). Market for Crabs (in Russian). [Electronic source] Available online: https://fas.gov.ru/documents/575522 (Date of access 11.05.2020)) but by 2016 these figures decreased to 60 companies, 100 ships, and 3000 crew members. (Kamchatsky Krai (2017). Crabs Market Segment (in Russian). 19 December 2017. [Electronic source] URL: http://kam-kray.ru/news/12951-krabovyi-segment.html (Date of access 11.05.2020)) Specialists note that each sailor provides employment to five workers onshore. (Kamchatka Krai (2017) Crabbing Sector (in Russian). 12 December 2017. http://kam-kray.ru/news/12951-krabovyi-segment.html (Date of access 30.07.2020)) Consequently, since the beginning of the 2000s, about 42,000 jobs could have been lost in the crab industry.

Many factors combined to produce these harmful phenomena. The complex legal rights for shared natural marine resources, the weak capacity of state institutions to create and enforce rules of production, and the lack of international cooperation between exporters and importers were all relevant, especially during the 1990s and 2000s [18]. To this list of causes, we would now add a shortage of reliable information on shadow activity and the corresponding lack of public interest. Although, in the authors' opinion, it should be possible to eliminate these factors by supplementing the "traditional" analysis of the shadow economy with new data mined from the media. This could activate powerful forces of public opinion for reducing the shadow economy by imposing an additional social cost on non-complying businesses.

\section{Russian Media and the Dynamics of IUU Crab Trade: Methodology and Results}

Let us take a closer look at the potential benefits of studying the shadow economy through the media, in contrast with the comparison of TAC with total imports that were actually used, to confront the Russian crab problem. To do this, we first conducted an analysis of print and electronic, federal and regional media for the period from 1996 to 2016, using previously developed techniques [19]. After 
that, we tested our hypothesis concerning the relationship between the published materials and the size of the shadow economy.

We searched the Web of Science database on 27 July 2020 and obtained 275 hits for the keywords "IUU" and 258 hits for "IUU fishing." None of the papers we found were related to mass media and its use to measure a shadow economy. Our search for "shadow economy" and "mass media" returned one paper mentioning the importance of mass media activities in fighting corruption [20]. We also found some evidence that mass media coverage of armed conflicts influences the stock prices of the companies involved and can be helpful in detecting illegal arms trade [21]. While the mass media seems to report on illegal economic activity, to our knowledge, there are no previous examples of quantitative studies of mass media to measure illegal, unreported, and unregulated activities. Therefore, we believe our approach is a novel way to study the scale of a shadow economy and use the illicit crab trade and related media coverage as an example.

The first step in the analysis was to use author assessment to select the keywords (KWs) or search terms that will accurately reflect the topic or issue under consideration, which in this case was the illegal harvesting of crab from the Far Eastern basin and its subsequent unregistered export to the largest consumers (Japan, China, Korea, Canada, and the US). The chosen KWs need to accurately reflect the technological process, the region of interest, and the most salient features of the particular shadow economy. For this example, it was decided to split the KWs into two types: Type 1-general characteristics of the sphere of interest; and Type 2-specific markers for the presence of the shadow component. The keywords (translated from Russian) chosen were: Type 1-“crab statistics", "allowable catch", "catch quota", "crab export", "crab Primorsky Krai"; Type 2-“illegal crab", "crab poaching", "illegal fishing Far East", "illegal export Japan", "illegal fishing vessel". Applying each type of keyword to the region's publications made for a total of $20 \mathrm{KWs}$ ( 10 for the federal and another 10 for the regional media).

The second step was to determine the sources for monitoring, again based on expert assessment. We selected a list of Russian media that included approximately 1500 regularly issued federal (Izvestiya, Kommersant, Nezavisimaya Gazeta, Rossiyskaya Gazeta, Rybatskie Vedomosti, etc.) and regional (Kamchatskoe Vremya, Kolymsky Trakt, Amurskie Vedomosti, Rybak Primoriya, Rybak Sakhalina, etc.) publications. Including a large number of sources is essential for effective analysis and a fundamental statistical requirement when using big data research methods.

The final step in the analysis was to continuously monitor the usage of the selected KWs in the source media for the relevant time period. For this example, the total number of references was tabulated separately for federal and regional media, as well as for the first (characteristics of the industry development) and second (markers of shadow activity) types of KWs (Figure 1, Table 1).

The total number of keyword references for 1996-2016 was 1108, of which $36.2 \%$ were found in federal and $63.8 \%$ in regional media. Almost all the articles were published in the harvesting regions, such as Sakhalin, Magadan, Kamchatka, Primorsky, and Khabarovsky provinces. This reflects the interest of regional media in an important branch of the local economy. The references to the keywords of the first type (KW-1: characteristics of the crab industry) slightly outnumber references to KW-2 (IUU markers) (54.9\% vs. $45.1 \%$ ). This is also understandable since the shadow sector is only a part of the economic activity associated with the harvesting and sale of crab. 


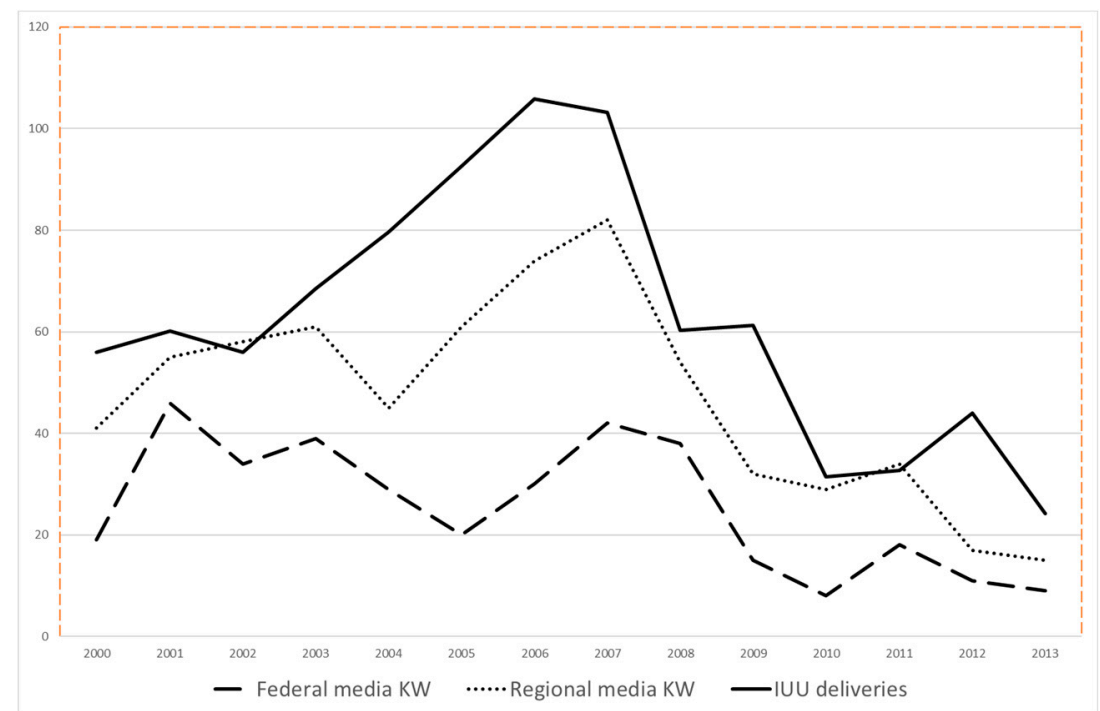

Figure 1. IUU deliveries of crab (1000 tons) and related keywords (cases). Sources: WWF, 2014 (IUU deliveries); the authors' data (related keywords), obtained on the basis of the methodology described above.

Table 1. Crab trade and keywords distribution (shortened, detailed data available in Appendix A).

\begin{tabular}{|c|c|c|c|c|c|c|}
\hline Year & 2000 & 2005 & 2010 & 2011 & 2012 & 2013 \\
\hline \multicolumn{7}{|l|}{ IUU crab * } \\
\hline Import ** & 120.5 & 149.5 & 83.1 & 82.5 & 93.9 & 85.8 \\
\hline $\mathrm{TAC}^{* * *}$ & 64.5 & 56.9 & 51.7 & 49.8 & 49.9 & 61.6 \\
\hline IUU deliveries $* * * *$ & 56.0 & 92.6 & 31.4 & 32.7 & 44.0 & 24.2 \\
\hline \multicolumn{7}{|l|}{ Keywords ***** } \\
\hline Total, including: & 60 & 81 & 37 & 52 & 28 & 24 \\
\hline Federal media & 19 & 20 & 8 & 18 & 11 & 9 \\
\hline Regional media & 41 & 61 & 29 & 34 & 17 & 15 \\
\hline KW-1 (industry features) & 46 & 39 & 25 & 26 & 14 & 9 \\
\hline KW-2 (IUU markers) & 14 & 42 & 12 & 26 & 14 & 15 \\
\hline \multicolumn{7}{|c|}{ Normalized Data } \\
\hline \multicolumn{7}{|l|}{ IUU crab * } \\
\hline Import $* *$ & 100 & 100 & 100 & 100 & 100 & 100 \\
\hline $\mathrm{TAC}^{* * *}$ & 54 & 38 & 62 & 60 & 53 & 72 \\
\hline IUU deliveries $* * * *$ & 46 & 62 & 38 & 40 & 47 & 28 \\
\hline \multicolumn{7}{|l|}{ Keywords ***** } \\
\hline Total, including: & 100 & 100 & 100 & 100 & 100 & 100 \\
\hline Federal media & 32 & 25 & 22 & 35 & 39 & 38 \\
\hline Regional media & 68 & 75 & 78 & 65 & 61 & 63 \\
\hline KW-1 (industry features) & 77 & 48 & 68 & 50 & 50 & 38 \\
\hline KW-2 (IUU markers) & 23 & 52 & 32 & 50 & 50 & 63 \\
\hline
\end{tabular}

Sources: * WWF, 2014; ${ }^{* *}$ total imports of Russian crab according to customs statistics of the largest importing countries (Canada, China, Japan, South Korea, USA), 1000 tons; *** total allowed catch (TAC), 1000 tons; **** import minus TAC, 1000 tons; ${ }^{* * * * *}$ the authors' data, obtained on the basis of the methodology described above. 
From this starting point, we could proceed to a more in-depth evaluation of the results and formulate the following research questions. First, is there really a correlation between shadow activity and the frequency of individual keywords? Second, is there a correlation in the analysis of data with a time lag of 1-2 years (that is, whether it is possible to use the media to predict future shadow activity). Finally, which KWs are the best indicators and how exactly are they related to the dynamics of the informal sector?

The study period covers the 14 years from 2000 to 2013, since it is for this time period that sufficient data on IUU crab exports exists. The estimation model is described by the following formula:

$$
Y=\mu+\sum_{i=1}^{n} \beta_{i} K e y_{i}+\varepsilon
$$

where $Y$ is the dependent variable, that is, the amount of shadow crab exported from Russia to the main importer countries in thousands of tons (the difference between total exports and TACs, Table 1); $\mu$ a constant; Key a vector of independent variables (the number of media references for each of the keywords); $\beta$ the coefficient of partial correlation; and $\varepsilon$ the standard error of the estimate. The scale of the variables is roughly equal (e.g., in 2000, unreported crab is roughly 56 (thousand tons) and the number of registered KWs is 60 ). This allowed us to proceed without the transformation of variables and use direct observations in calculations.

The estimation technique is based on the performance of multiple linear regression analysis. Our focus is on a comparatively simple analysis of the correlation between the frequency of keywords and the amount of illegal crab trade. With this in mind, we applied a "screen and clean" selection process and reduced the number of variables in our regression models in a single step. Additional independent variables were added progressively, and those that did not improve the coefficient of determination or had a low statistical significance (variables with less explanatory power) were ignored. Nevertheless, a more sophisticated approach may require the use of AIC or other methods for variable selection. The results of the best fitting models are given in Table 2 .

We will try to comment on the results and answer the questions posed above. First, the calculations show that there is a close and statistically significant correlation between the dependent and independent variables. Indeed, the coefficients of determination vary from 0.884 to 0.997 , depending on the estimation model used. Indicators of statistical significance and other characteristics are within acceptable limits. This confirms the existence of a close relationship between shadow activity levels and KW frequency in the studied media.

Second, to test the effect of time lags between media reporting and the level of illegal activity, we regressed the dependent variable for year $t$ against the set of independent variables for the years $t$ +1 and $t-1$. The use of a time lag between dependent and independent variables systematically worsens all the indicators, to the point any significant correlation is eliminated. It turns out that the connection between the number of publications and the shadow activity exists only for the same year. One possible explanation is that the current law on mass media (enacted in 2008) establishes a relatively short period for state authorities to react to journalists' information requests (e.g., the police must respond within seven days or provide a reasoned refusal within three days). This potentially shortens the time lag between media reports and their consequences. Another line of thought allows us to speculate that the mass media in Russia can attract public interest for a short period, but as a "Fourth Power" it is not influential enough to produce long-lasting social effects. 
Table 2. Correlation of IUU activities in the crab industry and the number of references to selected keywords in the Russian media (dependent variable: IUU imports of crab from Russia by largest importing countries, multiply regression, OLS estimate).

\begin{tabular}{|c|c|c|c|c|}
\hline Estimation Model & 1 & 2 & 3 & 4 \\
\hline Number of Independent Variables & 11 & 10 & 3 & 2 \\
\hline \multicolumn{5}{|c|}{$\beta$ for independent variables } \\
\hline \multicolumn{5}{|c|}{ (statistical significance): } \\
\hline \multirow{2}{*}{ illegal fishing Far East-fed } & 0.052 & & & \\
\hline & $(0.27)$ & & & \\
\hline \multirow{2}{*}{ crab Primorsky Krai-reg } & 0.096 & 0.078 & & \\
\hline & $(0.06)$ & $(0.06)$ & & \\
\hline \multirow{2}{*}{ crab export-reg } & 0.168 & 0.201 & & \\
\hline & $(0.05)$ & $(0.01)$ & & \\
\hline \multirow{2}{*}{ allowable catch-reg } & -0.12 & -0.11 & & \\
\hline & $(0.04)$ & $(0.03)$ & & \\
\hline \multirow{2}{*}{ illegal crab-fed } & 0.207 & 0.226 & & \\
\hline & $(0.02)$ & $(0.01)$ & & \\
\hline \multirow{2}{*}{ crab export-fed } & 0.139 & 0.102 & & \\
\hline & $(0.07)$ & $(0.06)$ & & \\
\hline \multirow{2}{*}{ catch quota-fed } & 0.197 & 0.207 & & \\
\hline & $(0.02)$ & $(0.01)$ & & \\
\hline \multirow[t]{2}{*}{ illegal fishing Far East-reg } & -0.18 & -0.18 & & \\
\hline & $(0.03)$ & $(0.02)$ & & \\
\hline \multirow{2}{*}{ allowable catch-fed } & 0.143 & 0.148 & 0.201 & \\
\hline & $(0.02)$ & $(0.01)$ & $(0.04)$ & \\
\hline \multirow{2}{*}{ catch quota-reg } & 0.748 & 0.762 & 0.857 & 0.905 \\
\hline & $(0.01)$ & $(0.01)$ & $(0.01)$ & $(0.01)$ \\
\hline \multirow{2}{*}{ illegal crab-reg } & -0.48 & -0.51 & -0.56 & -0.52 \\
\hline & $(0.01)$ & $(0.01)$ & $(0.01)$ & $(0.01)$ \\
\hline Adjusted R2 & 0.997 & 0.995 & 0.918 & 0.884 \\
\hline F-test & 410.4 & 308.3 & 50.12 & 50.64 \\
\hline Standard Error & 1.374 & 1.662 & 7.293 & 8.716 \\
\hline
\end{tabular}

Third, 11 out of the 20 selected keywords improve the regression results, with $10 \mathrm{KWs}$ having a high (0.01-0.06) statistical significance. This supports our choice of KWs and confirms the effectiveness of the method of using authors' assessment for selecting them.

It is important to note that the variables can be divided into two types, those with positive signs and those with negative signs. One-third of the significant coefficients $\beta$ are negative. For example, there is a negative correlation between shadow activity and the appearance of the "allowed catch" KW in federal, as well as "illegal crab" and "illegal fishing in the Far East" in regional media. The negative correlations represent somewhat unexpected results, as the conventional logic is that the greater shadow activity should be reflected in the increased use of related KWs. At the same time, the literature hints that this is not always the case. For instance, in European countries, the relationship between the tax burden and the shadow economy can be inconsistent depending on the institutional 
setting, showing both tax avoidance and the willingness to pay more taxes [22]. Potentially, in our case, it is possible to speak about a cause-and-effect relationship, where an increase in KW use causes a decrease in shadow activity. At least, existing evidence indicates that prosecutors built some cases on media reports and brought violators to court, thereby reducing illegal activity. (Fishkamchatka.ru (2020) State and poaching: who is winning (in Russian). http://fishkamchatka.ru/wild_salmon_of_ the_north_pacific/details/2858/12742_gosudarstvo_i_brakonerstvo_kto_pobezhdaet/ (Date of access 30.07.2020)). This fact can be interpreted as evidence that media attention can be an effective weapon in the fight against illegal practices.

In general, these results provide clear answers to the posed research questions and draw an understandable and logically complete picture. However, the peculiarities of the applied multiple regression and OLS estimation method and negative signs of some variables hint at the need for an additional check. In particular, the analysis of independent variables indicates the existence of some multicollinearity (see Appendix B for relevant data), which is eliminated by reducing their number. Nevertheless, even the use of only two variables (the fourth estimation model from Table 2) explains nearly $90 \%$ of the variation in the level of shadow activity $(\mathrm{R} 2=0.884)$.

In this case, the two variables barely correlate with each other (the collinearity of the pair is about 0.2 ) and there is a very high statistical significance (0.01). In addition, the values of $\beta$ obtained have different signs and equal 0.905 for "Catch Quota-reg" and -0.520 for "Illegal Crab-reg". Consequently, two types of correlation, both positive and negative, are present. All this suggests Estimation Model 4 is an excellent starting point for further analysis.

In order to perform an additional check, we introduced features of the regional economy into Equation (1) and switch to logarithms because the independent variables use considerably different scales. The new estimation model takes the following form:

$$
\ln Y=\mu+\sum_{i=1}^{n} \beta_{i} \ln \operatorname{Key}_{i}+\sum_{j=1}^{m} \beta_{j} \ln \operatorname{Con}_{j}+\varepsilon
$$

where Con is a vector of control variables that reflect the characteristics of crab harvesting regions.

We selected the control variables based on the recommendations of existing literature. We obtained the relevant data from publications by the Federal State Statistic Service and then computed a simple average of each variable for the five main provinces (Kamchatsky, Primorsky, Khabarovsky, Magadan, and Sakhalin). Of several candidate variables, we selected only two; namely, the percentage ratio of regional budget revenues to gross regional product (GRP) and the number of murders per 100,000 people. Both have a high statistical significance, improve regression results, and do not correlate to other independent variables.

The share of local budgets' tax revenues in GRP reflects the tax burden on all businesses in the region including fishing. A number of studies have found that excessive taxation leads to increased incentives for tax evasion, and thus to the expansion of shadow activities [23,24]. The tax burden on the fishing industry in the Russian Far East has been long considered as truly excessive, reaching $26.4 \%$ of the sales value in 2007. This, among other related factors, made entrepreneurs "go into the shadows", which our model reflected. Excessive taxation was a topic of lively discussion in local media. (Fishkamchatka.ru (2007) Problems of the fishery complex of the country and the main tasks to overcome them (in Russian). http://fishkamchatka.ru/library/books/2765/12230_glava_8_problemy_ rybokhozyaystvennogo_kompleksa_strany_i_osnovnye_zadachi_po_ikh_preodoleniyu/ (Date of access 30.07.2020)). At the request of the industrial association, Far Eastern fishery companies were granted generous tax breaks. As a result, the share of taxes in sales has almost halved, averaging out to $13.4 \%$ in 2008-2015. It should be noted that during these years a considerable reduction in the shadow exports was observed in Russian crabs trade. Thus, in the Russian institutional setting, reduced taxation resulted in weaker incentives for tax evasion and other types of shadow activity, including illegal crab harvesting. 
The number of murders is a standard indicator of general crime levels, overall security, and the social climate in the region. It should help predict shadow activity, including the more specific illegal harvesting and trading of crab. A positive correlation between homicides and the magnitude of shadow activities has been established in a number of publications $[25,26]$. According to available statistics, the number of murders in the Russian Far East increased from 1182 to 2348 in 1990-2005 and then declined to 769 in 2017. (Rosstat (2018) Regions of Russia (in Russian). Moscow: Rosstat, p. 434.) These dynamics also roughly coincide with our estimates of the shadow exports of crabs.

The estimation results show that the compiled model has high explanatory ability, and the $\beta$ coefficients for KW appearances retain their signs and high statistical significance (Table 3).

Table 3. Correlation of IUU activities in the crab industry, the number of references to selected keywords, and the selected characteristics of crab harvesting regions (dependent variable: IUU imports of crab from Russia by largest importing countries, multiply regression, OLS estimate).

\begin{tabular}{cc}
\hline Indicator & Value \\
\hline$\beta$ for independent variables (statistical significance): & \\
\hline Ratio of regional budget revenues to GRP & $0.292(0.05)$ \\
\hline Murders per 100 thousand of population & $0.562(0.04)$ \\
\hline Keyword References: & \\
\hline "Catch Quota-reg" & $0.397(0.05)$ \\
\hline "Illegal Crab-reg" & $-0.3(0.07)$ \\
\hline Adjusted R2 & 0.811 \\
\hline F-test & 0.911 \\
\hline Standard Error &
\end{tabular}

These findings confirm the results obtained using our previous approach. The "Illegal Crab" variable is negatively correlated with the IUU imports of crab from Russia. The mentioned considerations enable us to assert that the established correlation between the tax burden, the number of murders, and the dynamics of shadow activity is not accidental. Both of these indicators can be confidently used as independent (control) variables in our second model. It means that the impact of illicit harvesting and smuggling of natural resources stretches far beyond economics and affects the social fabric in producing areas. Therefore, the conducted robustness check not only further supports the previously obtained results but also hints at the need for a closer examination of regional context and a vigorous policy to avoid potentially negative consequences.

\section{Conclusions and Implications}

The findings of this study can be divided into three parts: the results of the statistical analysis; the role of the media; and policy implications.

First, it is highly possible that some media publications are closely correlated with the size of the shadow sector. Our results show that this is especially true for regional media reports. Using advanced statistical techniques, the study of relevant data can be an effective way to detect shadow activity. This method has several advantages and can function as a complement or alternative to existing approaches. The study of the correlation between media publications and the shadow economy should include the following steps: determining keywords; measuring their frequency; highlighting the indicators of shadow activity; clarifying the differences between federal and regional media reports; analyzing the correlation; selecting the best keywords based on their statistical significance; and verifying the final evaluation. The example of the crab industry shows that the use of the mentioned steps makes it possible to obtain important and well-grounded results. This indicates the possibility of applying 
the developed techniques to other areas of economic activity, including, perhaps most usefully, the extraction and foreign trade of renewable natural resources.

Second, the relationship between published media and shadow activities has at least two aspects. One is that newspapers and other news sources reflect the existence and dynamics of the shadow economy. By relying on a wide range of sources, the media pulls a unique set of information into circulation and allows us to explore the mechanism of shadow business. This leads to a positive correlation, since higher levels of shadow activity are accompanied by a greater number of relevant publications.

The other important aspect of the media is its public influence. As a shaper of public opinion, the media helps to determine the agenda of both central and regional government authorities and the decision-making process of businesses. This helps to explain the negative correlation between the number of relevant publications and activity in the shadow sector. It appears that the media stimulates the government to take a more active role in addressing reported issues and companies to avoid using controversial business methods. Obviously, effective control and international cooperation play a major role in the fight to stop illegal harvesting and smuggling of natural resources. Nevertheless, when the main part of the work has already been done, but sustainable results have not yet been obtained, we should focus on fine-tuning the control and cooperation mechanism. For this purpose, the media is an indispensable tool. More generally, the results of the study highlight the importance of strong governance, high public awareness, and active media in modern civil society. The results also indicate another potential use of media-mined data-based research.

Third, the shadow economy has a complex structure as reflected in a variety of media publications. This complexity creates the potential for unwanted and possibly severe side effects. For example, eliminating the illegal component of the crab trade was the main factor in a sharp decline in imports of crustaceans from Russia. The new transparent system of international trade made it possible to preserve resources and to establish long-term, sustainable, and mutually beneficial economic relations with partner countries, but, at the same time, hundreds of crab harvesting companies went bankrupt and thousands of fishermen lost their jobs. Furthermore, the price of Russian crab has increased, resulting in a loss of competitiveness and market share. The business, administrative and public circles have yet to work out a plan of action designed to balance the positive and negative effects of reducing the shadow business, despite the obvious need to develop such a program.

More than that, as our results indicate, the shadow economy is related to a wide range of pressing regional issues from optimal taxation to crime prevention. A sustainable solution for these problems could contribute to improving the business environment and strengthening the social fabric in local communities. For this, more objective and complete information is needed, as well as better tools for researching the relationship between media publications and shadow activity.

The analysis presented in this paper could continue in several directions. For one, it would certainly be worthwhile to verify these findings by testing the same method on another industry (for example, forestry), which has long contributed to the illicit extraction and export of a natural resource. A comparative international study of the countries importing Russian crabs (or timber) might also be quite interesting. Finally, semantic analysis of related media could prove important and ultimately provide additional information. Nevertheless, even in the current form, the method presented here might be of interest from both the scientific and practical viewpoints.

Author Contributions: A.B.: developed the theoretical framework, performed the numerical calculations and wrote the manuscript; G.S.: processed the media reports and collected the data for statistical analysis. Both authors provided critical feedback and helped shape the manuscript. All authors have read and agreed to the published version of the manuscript.

Funding: This research received no external funding.

Conflicts of Interest: The authors declare no conflict of interest. 


\section{Appendix A}

Raw data for Table 1.

Table A1. Keywords distribution and crab trade.

\begin{tabular}{cccccccc}
\hline & $\mathbf{2 0 0 0}$ & $\mathbf{2 0 0 1}$ & $\mathbf{2 0 0 2}$ & $\mathbf{2 0 0 3}$ & $\mathbf{2 0 0 4}$ & $\mathbf{2 0 0 5}$ & $\mathbf{2 0 0 6}$ \\
\hline Federal media & 19 & 46 & 34 & 39 & 29 & 20 & 30 \\
\hline Regional media & 41 & 55 & 58 & 61 & 45 & 61 & 74 \\
\hline Type 1 (industry features) & 46 & 56 & 47 & 56 & 54 & 39 & 59 \\
\hline Type 2 (IUU markers) & 14 & 45 & 45 & 44 & 20 & 42 & 45 \\
\hline
\end{tabular}

Federal media

\begin{tabular}{|c|c|c|c|c|c|c|c|}
\hline \multicolumn{8}{|l|}{ Type 1 (industry features) } \\
\hline crab statistics-fed & 3 & 4 & 6 & 5 & 6 & 3 & 3 \\
\hline allowable catch-fed & 0 & 3 & 0 & 1 & 0 & 0 & 0 \\
\hline catch quota-fed & 4 & 19 & 6 & 17 & 12 & 1 & 2 \\
\hline crab export-fed & 1 & 1 & 1 & 1 & 1 & 1 & 2 \\
\hline crab Primorsky Krai-fed & 5 & 2 & 1 & 0 & 1 & 2 & 4 \\
\hline \multicolumn{8}{|l|}{ Type 2 (IUU markers) } \\
\hline illegal crab-fed & 1 & 1 & 2 & 0 & 1 & 1 & 3 \\
\hline crab poaching-fed & 2 & 11 & 9 & 6 & 5 & 5 & 11 \\
\hline illegal fishing Far East-fed & 0 & 1 & 2 & 1 & 1 & 3 & 1 \\
\hline illegal export Japan-fed & 1 & 1 & 3 & 2 & 0 & 2 & 1 \\
\hline illegal fishing vessel-fed & 2 & 3 & 4 & 6 & 2 & 2 & 3 \\
\hline \multicolumn{8}{|l|}{ Regional media } \\
\hline \multicolumn{8}{|l|}{ Type 1 (industry features) } \\
\hline crab statistics-reg & 7 & 5 & 0 & 2 & 4 & 2 & 4 \\
\hline allowable catch-reg & 4 & 9 & 8 & 2 & 6 & 3 & 11 \\
\hline catch quota-reg & 6 & 8 & 15 & 19 & 15 & 13 & 20 \\
\hline crab export-reg & 0 & 0 & 3 & 1 & 1 & 2 & 1 \\
\hline crab Primorsky Krai-reg & 16 & 5 & 7 & 8 & 8 & 12 & 12 \\
\hline \multicolumn{8}{|l|}{ Type 2 (IUU markers) } \\
\hline illegal crab-reg & 1 & 3 & 5 & 5 & 2 & 0 & 1 \\
\hline crab poaching-reg & 2 & 20 & 9 & 10 & 4 & 22 & 14 \\
\hline illegal fishing Far East-reg & 2 & 1 & 3 & 3 & 2 & 2 & 1 \\
\hline illegal export Japan-reg & 1 & 1 & 3 & 3 & 1 & 0 & 2 \\
\hline illegal fishing vessel-reg & 2 & 3 & 5 & 8 & 2 & 5 & 8 \\
\hline Import & 120.5 & 119.1 & 113.2 & 132.7 & 137.8 & 149.5 & 178.6 \\
\hline TAC & 64.5 & 58.9 & 57.3 & 64.2 & 58.1 & 56.9 & 72.8 \\
\hline IUU deliveries & 56 & 60.2 & 55.9 & 68.5 & 79.7 & 92.6 & 105.8 \\
\hline
\end{tabular}


Table A1. Cont.

\begin{tabular}{|c|c|c|c|c|c|c|c|}
\hline & 2007 & 2008 & 2009 & 2010 & 2011 & 2012 & 2013 \\
\hline Federal media & 42 & 38 & 15 & 8 & 18 & 11 & 9 \\
\hline Type 1 (industry features) & 82 & 54 & 32 & 29 & 34 & 17 & 15 \\
\hline crab statistics-fed & 63 & 48 & 25 & 25 & 26 & 14 & 9 \\
\hline allowable catch-fed & 61 & 44 & 22 & 12 & 26 & 14 & 15 \\
\hline \multicolumn{8}{|l|}{ catch quota-fed } \\
\hline \multicolumn{8}{|l|}{ crab export-fed } \\
\hline crab Primorsky Krai-fed & 4 & 5 & 1 & 4 & 2 & 2 & 0 \\
\hline Type 2 (IUU markers) & 4 & 1 & 2 & 0 & 1 & 0 & 0 \\
\hline illegal crab-fed & 3 & 2 & 1 & 1 & 1 & 0 & 2 \\
\hline crab poaching-fed & 0 & 0 & 2 & 0 & 0 & 0 & 0 \\
\hline illegal fishing Far East-fed & 7 & 7 & 4 & 1 & 4 & 2 & 2 \\
\hline \multicolumn{8}{|l|}{ illegal export Japan-fed } \\
\hline illegal fishing vessel-fed & 4 & 5 & 1 & 0 & 1 & 4 & 2 \\
\hline Regional media & 6 & 10 & 0 & 0 & 2 & 1 & 1 \\
\hline Type 1 (industry features) & 3 & 2 & 0 & 0 & 2 & 2 & 0 \\
\hline crab statistics-reg & 4 & 1 & 1 & 0 & 2 & 0 & 1 \\
\hline allowable catch-reg & 7 & 5 & 3 & 2 & 3 & 0 & 1 \\
\hline \multicolumn{8}{|l|}{ catch quota-reg } \\
\hline \multicolumn{8}{|l|}{ crab export-reg } \\
\hline crab Primorsky Krai-reg & 3 & 8 & 0 & 1 & 6 & 0 & 0 \\
\hline Type 2 (IUU markers) & 4 & 6 & 4 & 3 & 4 & 1 & 0 \\
\hline illegal crab-reg & 24 & 5 & 5 & 8 & 7 & 4 & 1 \\
\hline crab poaching-reg & 2 & 0 & 1 & 0 & 0 & 0 & 0 \\
\hline illegal fishing Far East-reg & 12 & 14 & 5 & 7 & 1 & 5 & 4 \\
\hline \multicolumn{8}{|l|}{ illegal export Japan-reg } \\
\hline illegal fishing vessel-reg & 4 & 2 & 2 & 4 & 3 & 3 & 3 \\
\hline Federal media & 14 & 7 & 6 & 0 & 2 & 3 & 5 \\
\hline Type 1 (industry features) & 3 & 1 & 0 & 0 & 2 & 0 & 1 \\
\hline crab statistics-fed & 1 & 1 & 0 & 1 & 1 & 0 & 1 \\
\hline allowable catch-fed & 15 & 10 & 9 & 5 & 8 & 1 & 0 \\
\hline Import & 176.7 & 129.5 & 122 & 83.1 & 82.5 & 93.9 & 85.8 \\
\hline TAC & 73.5 & 69.2 & 60.8 & 51.7 & 49.8 & 49.9 & 61.6 \\
\hline IUU deliveries & 103.2 & 60.3 & 61.2 & 31.4 & 32.7 & 44 & 24.2 \\
\hline
\end{tabular}

Source: The same as for Table 1.

\section{Appendix B}

Correlations of variables in Table 2. 
Table A2. Correlations of variables in Table 2, estimation model 1 (11 variables).

\begin{tabular}{|c|c|c|c|c|c|c|c|}
\hline & & 1 & 2 & 3 & 4 & 5 & 6 \\
\hline 1 & allowable catch-fed & 1.00 & -0.20 & -0.11 & -0.16 & -0.18 & 0.06 \\
\hline 2 & catch quota-fed & -0.20 & 1.00 & -0.40 & 0.35 & -0.25 & -0.24 \\
\hline 3 & crab export-fed & -0.11 & -0.40 & 1.00 & -0.03 & 0.66 & -0.34 \\
\hline 4 & illegal crab-fed & -0.16 & 0.35 & -0.03 & 1.00 & -0.48 & -0.31 \\
\hline 5 & illegal fishing Far East-fed & -0.18 & -0.25 & 0.66 & -0.48 & 1.00 & -0.08 \\
\hline 6 & allowable catch-reg & 0.06 & -0.24 & -0.34 & -0.31 & -0.08 & 1.00 \\
\hline 7 & catch quota-reg & -0.14 & 0.07 & -0.29 & 0.19 & -0.34 & -0.18 \\
\hline 8 & crab export-reg & 0.14 & 0.52 & -0.72 & 0.17 & -0.61 & 0.08 \\
\hline 9 & crab Primorsky Krai-reg & 0.04 & -0.13 & 0.28 & -0.50 & 0.48 & 0.01 \\
\hline 10 & illegal crab-reg & -0.14 & -0.45 & 0.70 & -0.34 & 0.68 & 0.00 \\
\hline \multirow[t]{2}{*}{11} & illegal fishing Far East-reg & 0.07 & -0.39 & 0.25 & 0.25 & -0.14 & 0.07 \\
\hline & & 7 & 8 & 9 & 10 & 11 & \\
\hline 1 & allowable catch-fed & -0.14 & 0.14 & 0.04 & -0.14 & 0.07 & \\
\hline 2 & catch quota-fed & 0.07 & 0.52 & -0.13 & -0.45 & -0.39 & \\
\hline 3 & crab export-fed & -0.29 & -0.72 & 0.28 & 0.70 & 0.25 & \\
\hline 4 & illegal crab-fed & 0.19 & 0.17 & -0.50 & -0.34 & 0.25 & \\
\hline 5 & illegal fishing Far East-fed & -0.34 & -0.61 & 0.48 & 0.68 & -0.14 & \\
\hline 6 & allowable catch-reg & -0.18 & 0.08 & 0.01 & 0.00 & 0.07 & \\
\hline 7 & catch quota-reg & 1.00 & -0.03 & -0.42 & -0.38 & -0.21 & \\
\hline 8 & crab export-reg & -0.03 & 1.00 & -0.19 & -0.58 & -0.36 & \\
\hline 9 & crab Primorsky Krai-reg & -0.42 & -0.19 & 1.00 & 0.62 & -0.28 & \\
\hline 10 & illegal crab-reg & -0.38 & -0.58 & 0.62 & 1.00 & -0.02 & \\
\hline 11 & illegal fishing Far East-reg & -0.21 & -0.36 & -0.28 & -0.02 & 1.00 & \\
\hline
\end{tabular}

Table A3. Correlations of variables in Table 2, estimation model 2 (10 variables).

\begin{tabular}{ccccccc}
\hline & & $\mathbf{1}$ & $\mathbf{2}$ & $\mathbf{3}$ & $\mathbf{4}$ & $\mathbf{5}$ \\
\hline 1 & allowable catch-fed & 1.00 & -0.25 & 0.01 & -0.29 & 0.05 \\
\hline 2 & catch quota-fed & -0.25 & 1.00 & -0.33 & 0.28 & -0.27 \\
\hline 3 & crab export-fed & 0.01 & -0.33 & 1.00 & 0.44 & -0.39 \\
\hline 4 & illegal crab-fed & -0.29 & 0.28 & 0.44 & 1.00 & -0.40 \\
\hline 5 & allowable catch-reg & 0.05 & -0.27 & -0.39 & -0.40 & 1.00 \\
\hline 6 & catch quota-reg & -0.22 & -0.01 & -0.10 & 0.03 & -0.22 \\
\hline 7 & crab export-reg & 0.03 & 0.48 & -0.53 & -0.17 & 0.04 \\
\hline 8 & crab Primorsky Krai-reg & 0.14 & -0.02 & -0.05 & -0.35 & 0.06 \\
\hline 9 & illegal crab-reg & -0.03 & -0.39 & 0.46 & -0.01 & 0.07 \\
\hline 10 & illegal fishing Far East-reg & 0.05 & -0.45 & 0.46 & 0.21 & 0.06 \\
\hline
\end{tabular}


Table A3. Cont.

\begin{tabular}{ccccccc}
\hline & & $\mathbf{6}$ & $\mathbf{7}$ & $\mathbf{8}$ & $\mathbf{9}$ & $\mathbf{1 0}$ \\
\hline 1 & allowable catch-fed & -0.22 & 0.03 & 0.14 & -0.03 & 0.05 \\
\hline 2 & catch quota-fed & -0.01 & 0.48 & -0.02 & -0.39 & -0.45 \\
\hline 3 & crab export-fed & -0.10 & -0.53 & -0.05 & 0.46 & 0.46 \\
\hline 4 & illegal crab-fed & 0.03 & -0.17 & -0.35 & -0.01 & 0.21 \\
\hline 5 & allowable catch-reg & -0.22 & 0.04 & 0.06 & 0.07 & 0.06 \\
\hline 6 & catch quota-reg & 1.00 & -0.31 & -0.31 & -0.22 & -0.28 \\
\hline 7 & crab export-reg & -0.31 & 1.00 & 0.14 & -0.29 & -0.56 \\
\hline 8 & crab Primorsky Krai-reg & -0.31 & 0.14 & 1.00 & 0.46 & -0.25 \\
\hline 10 & illegal crab-reg & -0.22 & -0.29 & 0.46 & 1.00 & 0.10 \\
\hline
\end{tabular}

Table A4. Correlations of variables in Table 2, estimation model 3 (three variables).

\begin{tabular}{ccccc}
\hline & & $\mathbf{1}$ & $\mathbf{2}$ & $\mathbf{3}$ \\
\hline 1 & allowable catch-fed & 1 & -0.24 & -0.21 \\
2 & catch quota-reg & -0.24 & 1 & -0.14 \\
3 & illegal crab-reg & -0.21 & -0.14 & 1 \\
\hline
\end{tabular}

Table A5. Correlations of variables in Table 2, estimation model 4 (two variables).

\begin{tabular}{clcc}
\hline & & $\mathbf{1}$ & $\mathbf{2}$ \\
\hline 1 & catch quota-reg & 1 & -0.20 \\
2 & illegal crab-reg & -0.20 & 1 \\
\hline \multicolumn{4}{c}{ Source: Authors' calculations. }
\end{tabular}

\section{References}

1. Bodman, P.M.; Campbell, H.F.; Skinner, R.B. The One That Got Away? Crime and Punishment in Queensland's Commercial Fisheries. Aust. Econ. Pap. 2002, 41, 320-328. [CrossRef]

2. Agnew, D.J.; Barnes, C.T. Economic Aspects and Drivers of IUU Fishing; AGR/FI/IUU OECD Report; OECD: Paris, France, 2004; Volume 2, 33p.

3. Jensen, C.L.; Aarset, B. Explaining noncompliance in the Norwegian coastal cod fishery: An application of the multinomial logit. Appl. Econ. 2008, 40, 505-513. [CrossRef]

4. Jensen, F.; Grønbæk, L. Random penalties and renewable resources: A mechanism to reach optimal landings in fisheries. Nat. Resour. Model. 2009, 22, 393-414. [CrossRef]

5. Hung, C.-M.; Weng, Y. Fishery Subsidies, Illegal Fuel Trading, and Conservation. Mar. Resour. Econ. 2012, 27, 253-265. [CrossRef]

6. Yamazaki, S.; Hoshino, E.; Resosudarmo, B.P. No-take marine reserves and illegal fishing under imperfect enforcement. Aust. J. Agric. Resour. Econ. 2014, 59, 334-354. [CrossRef]

7. Pascoe, S.; Okey, T.A.; Griffiths, S. Economic and ecosystem impacts of illegal, unregulated and unreported (IUU) fishing in Northern Australia. Aust. J. Agric. Resour. Econ. 2008, 52, 433-452. [CrossRef]

8. Macfadyen, G.; Caillart, B.; Agnew, D. Review of Studies Estimating Levels of IUU Fishing and the Methodologies Utilized; Poseidon Aquatic Resource Management Ltd.: Rome, Italy, 2016; [Electronic source]; Available online: http://www.fao.org/iuu-fishing/resources/detail/en/c/1132165/ (accessed on 11 November 2019). 
9. Marine Resources Assessment Group (MRAG). Review of Impacts of Illegal, Unreported and Unregulated Fishing on Developing Countries; A report prepared by MRAG for the UK's Department for International Development (DFID); MRAG: London, UK, 2005; 178p, [Electronic source]; Available online: https://mrag.co.uk/experience/ review-impacts-illegal-unreported-and-unregulated-iuu-fishing-developing-countries (accessed on 15 May 2020).

10. Organisation for Economic Cooperation and Development (OECD). Why Fish Piracy Persists: The Economics of IUU Fishing; OECD: Paris, France, 2005; 289p.

11. Agnew, D.J.; Pearce, J.; Pramod, G.; Peatman, T.; Watson, R.A.; Beddington, J.R.; Pitcher, T.J. Estimating the Worldwide Extent of Illegal Fishing. PLoS ONE 2009, 4, e4570. [CrossRef] [PubMed]

12. Meere, F. Fishing for Development; OECD TAD/FI Background Paper: Paris, France, 2014; [Electronic source]; Available online: https://www.oecd.org/tad/events/Fishing-for-development-2014-Session-2-Paper. pdf (accessed on 3 February 2019).

13. Österblom, H.; Sumaila, U.R.; Bodin, Ö.; Hentati-Sundberg, J.; Press, A.J. Adapting to Regional Enforcement: Fishing Down the Governance Index. PLoS ONE 2010, 5, e12832. [CrossRef] [PubMed]

14. Kaufmann, D.; Kraay, A.; Mastruzzi, M. Governance Matters III: Governance Indicators for 1996, 1998, 2000 and 2002. World Bank Econ. Rev. 2004, 18, 253-287. [CrossRef]

15. World Wildlife Fund (WWF). Illegal Russian Crab: An Investigation of Trade Flow; World Wildlife Fund: Washington, DC, USA, 2014; 40p.

16. Arai, N. Russia's export of seafood products to Japan: Difference between statistics and reality. Reg. Econ. Soc. 2004, 4, 82-96. (In Russian)

17. Pramod, G.; Pitcher, T.J.; Mantha, G. Estimates of illegal and unreported seafood imports to Japan. Mar. Policy 2017, 84, 42-51. [CrossRef]

18. Belov, A. Regional Dimension of Economic Cooperation between Japan and Russia. J. East-West Bus. 2005, 11, 119-140. [CrossRef]

19. Belov, A.V.; Soboleva, G.V. Using mass media to analyze the shadow economy. Vestnik SPBGU Ekonomika 2018, 31, 113-133. (In Russian) [CrossRef]

20. Skoryk, M.O. Theoretical aspects of the transformation of the institute of corruption in Eastern Europe. Balt. J. Econ. Stud. 2019, 5, 201-206. [CrossRef]

21. Vigna, D.S.; La Ferrara, E. Detecting Illegal Arms Trade. Am. Econ. J. Econ. Policy 2010, 2, 26-57. [CrossRef]

22. Tafenau, E.; Herwartz, H.; Schneider, F. Regional Estimates of the Shadow Economy in Europe. Int. Econ. J. 2010, 24, 629-636. [CrossRef]

23. Besley, T.; Persson, T. Why Do Developing Countries Tax So Little? J. Econ. Perspect. 2014, 28, 99-120. [CrossRef]

24. Reimers, O. Tax Evasion and the Shadow Economy; CESifo DICE Report; Leibniz Information Center for Economics: Munich, Germany, 2014; Volume 12, pp. 61-62, [Electronic source]; Available online: https:/www. econstor.eu/bitstream/10419/167192/1/ifo-dice-report-v12-y2014-i4-p61-62.pdf (accessed on 15 November 2019).

25. Tuttle, J. Murder in the shadows: Evidence for an institutional legitimacy theory of crime. Int. J. Comp. Appl. Crim. Justice 2017, 43, 13-27. [CrossRef]

26. Costanza, S.E.; Helms, R. Street Gangs and Aggregate Homicides: An Analysis of Effects during the 1990s Violent Crime Peak. Homicide Stud. 2011, 16, 280-307. [CrossRef]

(C) 2020 by the authors. Licensee MDPI, Basel, Switzerland. This article is an open access article distributed under the terms and conditions of the Creative Commons Attribution (CC BY) license (http://creativecommons.org/licenses/by/4.0/). 